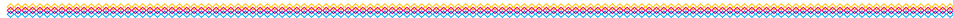

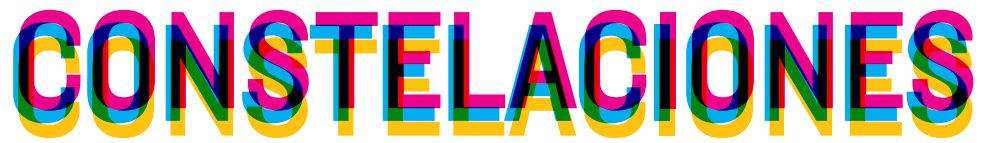

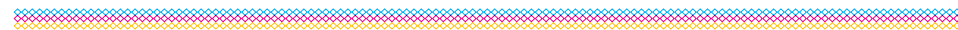


CONSTELACIONES nº6, mayo 2018

Revista de Arquitectura de la Universidad CEU San Pablo

Architecture Magazine of CEU San Pablo University

Periodicidad anual

Annual periodicity

COMITÉ DE REDACCIÓN EDITORIAL COMMITTEE

\section{Dirección Directors}

Juan García Millán

Santiago de Molina

Jefa de Redacción Editor in Chief

Covadonga Lorenzo Cueva

Secretario de Redacción Editorial Clerk

Rodrigo Núñez Carrasco

Maquetación y producción Design and production

Clara Martínez-Conde Rubio

Julia Ruiz-Cabello Subiela

Responsable Web Web Page Manager

María Isabel Castilla Heredia

Diseño Original Original Design

Juan Roldán Martín

\section{CONSEJO EDITORIAL EDITORIAL BOARD}

Beatriz Colomina. School of Architecture, Princeton University, New Jersey

Carmen Díez Medina. Escuela de Ingeniería y Arquitectura, Universidad de Zaragoza

María Antonia Frías Sargadoy. Escuela Técnica Superior de Arquitectura, Universidad de Navarra

Juan Miguel Hernández Léon. Escuela Técnica Superior de Arquitectura, Universidad Politécnica de Madrid Juan José Lahuerta Alsina. Escuela Técnica Superior de Arquitectura, Universidad Politécnica de Cataluña, Barcelona Eduardo Leira Sánchez. Ex director del Plan General de Ordenación Urbana, Madrid

Joaquín Medina Wamburg. Facultad de Aquitectura Diseño y Urbanismo, Universidad de Buenos Aires

Zaida Muxí Martínez. Escuela Técnica Superior de Arquitectura, Universidad Politécnica de Cataluña, Barcelona José Joaquín Parra Bañón. Escuela Técnica Superior de Arquitectura, Universidad de Sevilla

Víctor Pérez Escolano. Escuela Técnica Superior de Arquitectura, Universidad de Sevilla

Fernando Pérez Oyarzún. Escuela de Arquitectura y Diseño, Pontificia Universidad Católica, Santiago de Chile

Judith Sheine. School of Architecture and Allied Arts, University of Oregon, Portland

Andrés Walliser Martínez. Global Design, New York University, Nueva York

ISSN 2340-177X

Depósito legal M-13872-2013

(c) de los textos, sus autores

(c) de las imágenes autorizadas

(c) Revista Constelaciones

๑) Escuela Politécnica Superior, Universidad CEU San Pablo

Universidad CEU San Pablo

Escuela Politécnica Superior

Urbanización Montepríncipe, s/n

Alcorcón, 28925. Madrid (España)

constelaciones@eps.ceu.es

www.uspceu.es

www.revistaconstelaciones.wordpress.com

Edición Edition

Fundación Universitaria San Pablo CEU

Madrid, España

Impresión Printing

VA Impresores

Impreso en España Printed in Spain

Distribución Distribution

CEU Ediciones

\author{
INDEXACIÓN INDEXING \\ Índices Index \\ Latindex \\ Avery Index \\ ErihPlus \\ MIAR
}

Bases de datos Data bases

Dialnet

Índices en evaluación Evaluation Index

Web of Science

Scopus

Dulcinea

EBSCO

Sherpa Romeo

Los textos que componen Constelaciones se obtienen mediante convocatoria pública. Para que los trabajos recibidos entren en el proceso de selección de los artículos a publicar deben ser trabajos originales no publicados anteriormene, con una extensión recomendada de 3.000 palabras, título, resumen (un máximo de 150 palabras) y palabras clave (un mínimo de cuatro palabras), en español y en inglés. Tras haber cumplido estos requisitos (y los correspondientes incluidos en las normas editoriales de la revista, disponibles para consulta en formato digital desde el comienzo de la convocatoria), tiene lugar un proceso de revisión y evaluación de los artículos previa aceptación de los mismos para su publicación. Para acometer dicho proceso, y con el fin de asegurar la calidad de los contenidos, la revista Constelaciones recurre a evaluadores externos a la institución editora y anónimos (cada artículo es evaluado por dos de ellos) encargados de someter a crítica los mismos. Todos los artículos de investigación publicados en esta revista han pasado por dicho proceso. La recepción de artículos se extendió hasta el 30 de septiembre de 2017. Texts included in Constelaciones are obtained by public announcement. Only original papers that have not been previously published will be included in the process of selection of articles. They should not exceed 3.000 words and should include a title, an abstract (no more than 150 words) and keywords (a minimum of four words), in Spanish and English. After having fulfilled these requirements (and those included in magazine editorial standards, available for consultation from the beginning of the Call for Papers), occurs a process of review and evaluation of articles upon acceptance of them for publication. To undertake this process, and in order to ensure the quality of the contents, Constelaciones turns to external and anonymous evaluators to the institution (each article is evaluated by two of them) responsible for the critic. All the articles published in this journal have undergone this process. The deadline for reception was extended until September 30, 2017.

Todos los derechos reservados. Esta publicación no puede ser reproducida, ni en todo ni en parte, ni registrada, ni transmitida, ni almacenada en ninguna forma ni por ningún medio, sin la autorización previa y por escrito del equipo editorial. En este número se han utilizado algunas imágenes de las que no se ha podido identificar al propietario de los derechos. En estos casos hemos entendido que las imágenes son de libre uso. En caso de identificar alguna de estas imágenes como propia, por favor, póngase en contacto con la redacción de Constelaciones. Los criterios expuestos en los diversos artículos de la revista son responsabilidad exclusiva de sus autores y no reflejan necesariamente los que pueda tener el equipo editoral. El equipo editorial de la revista no se responsabiliza de devolver la información enviada a la redacción a no ser que se le solicite expresamente. All rights reserved. This publication cannot be reproduced, in whole or in part, nor registered, transmitted or stored in any form or by any means, without the written permission of the Editorial team, In this issue some images were used without knowing the owner of the rights. In these cases, we have understood that the images are free of use. In case you identify shared by the editors of this journal. The publisher don't take responsibility for returning submitted material which is not expressly requested. 


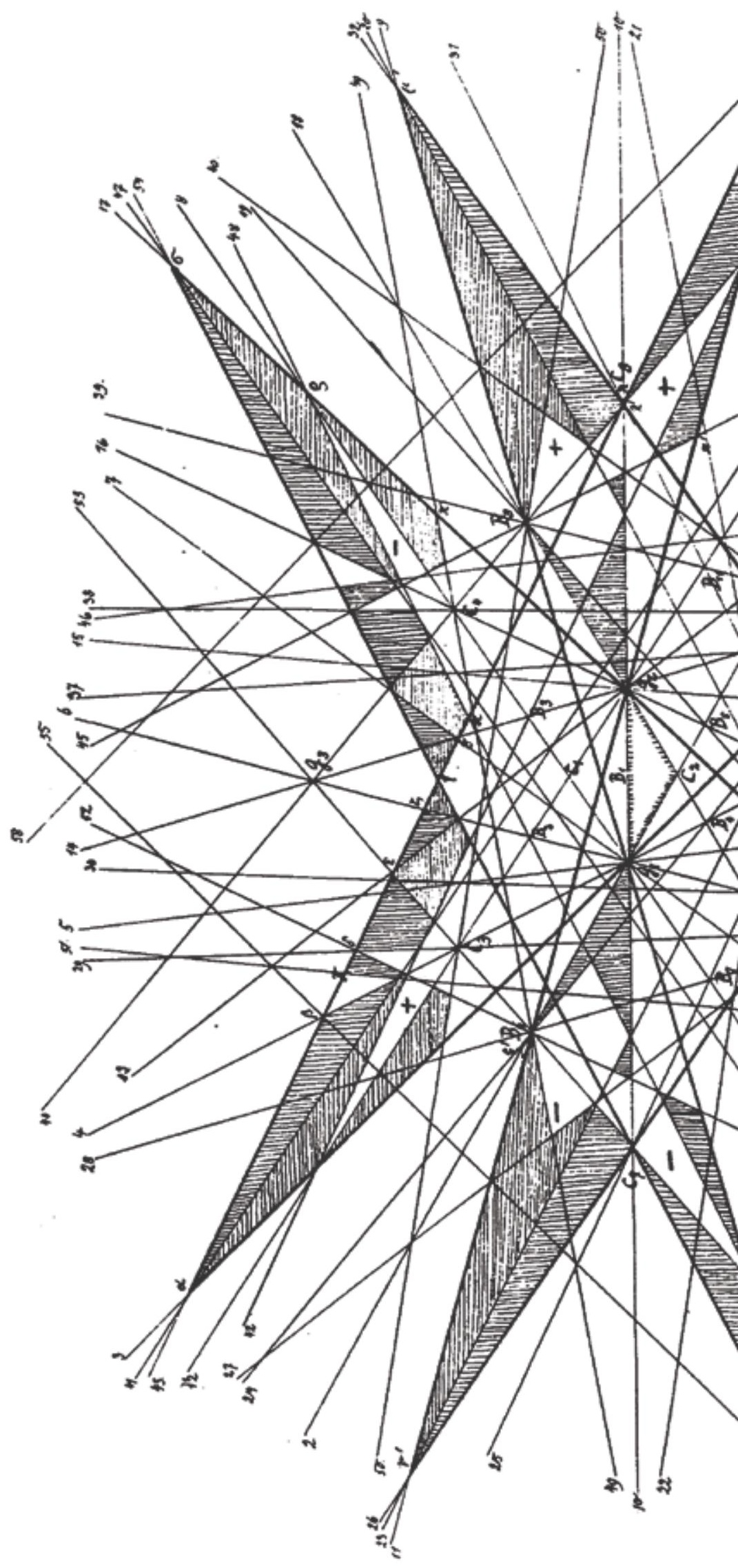




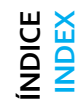

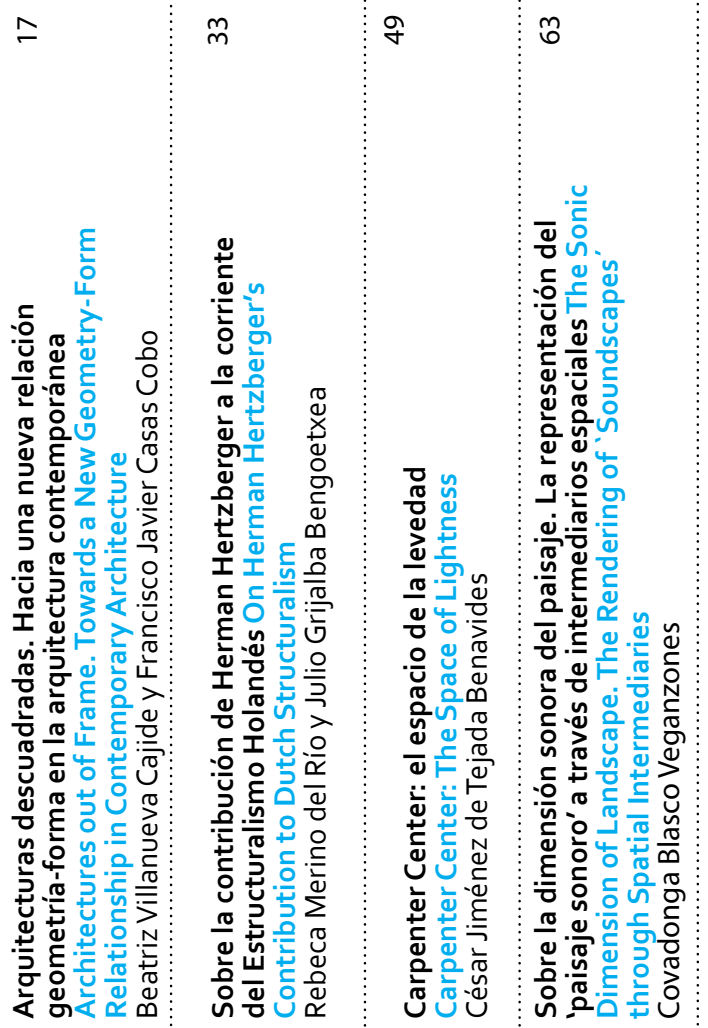

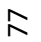

ต

$\leftleftarrows$

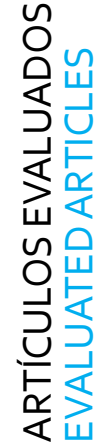

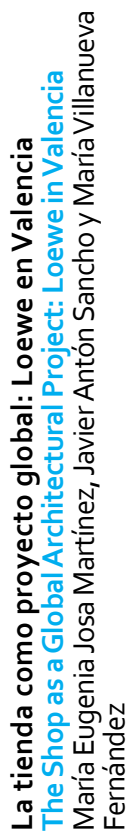

윰 可

틈응

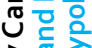

울을

I0

율

동

능

잉이

용요

ब雨

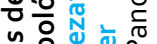

은음

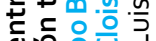

넌은 을겅

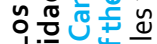

능뭉ㅎㅇㅇㅇㅇ

荇

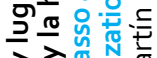

入入⿻

준

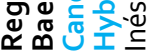
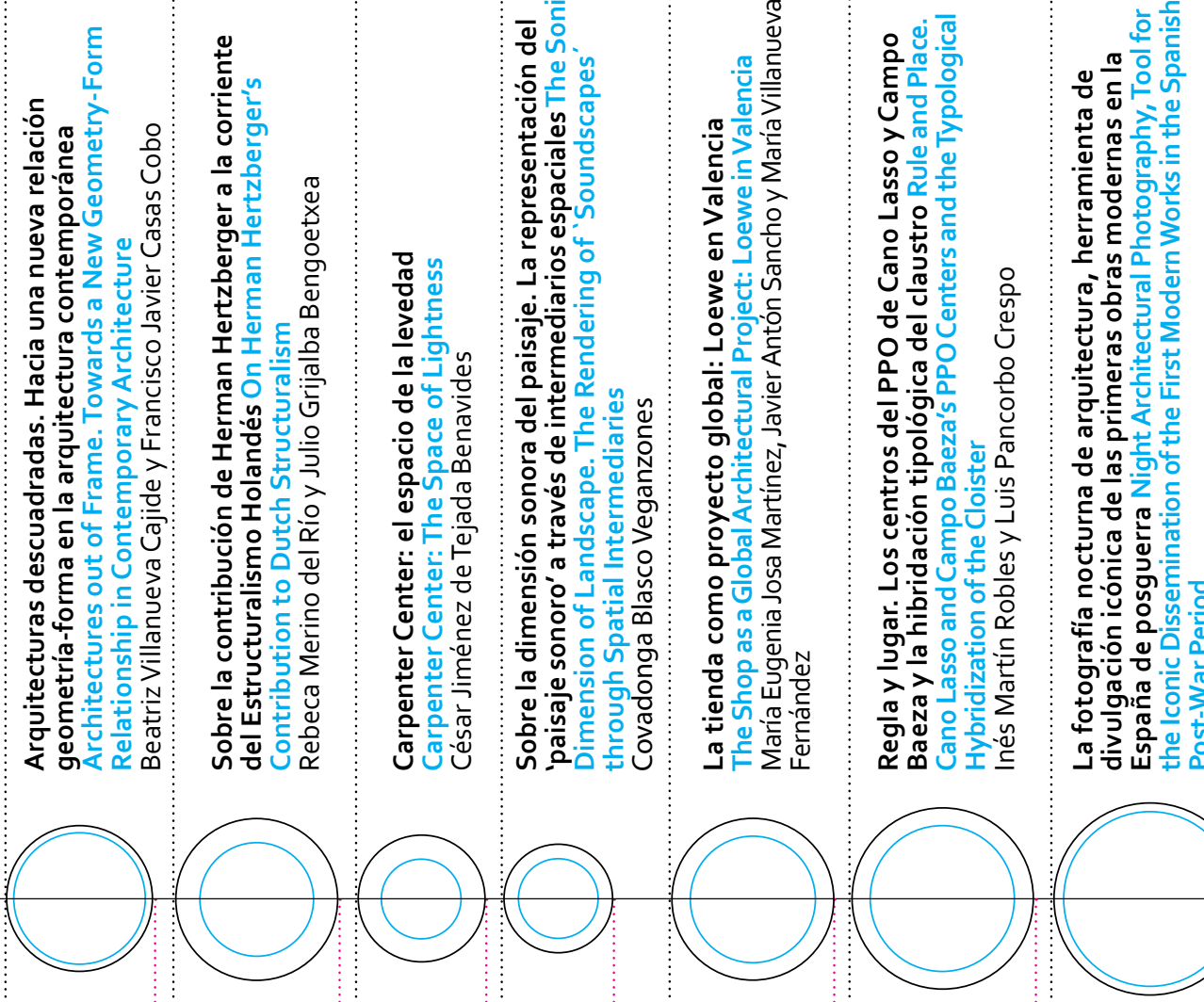

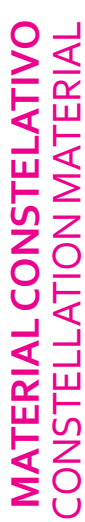

岂㟧

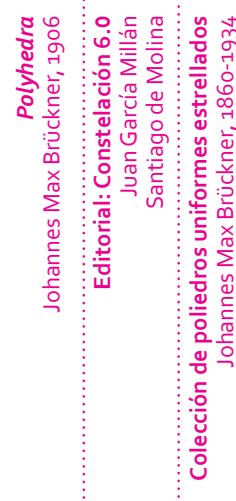

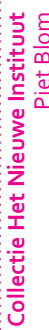
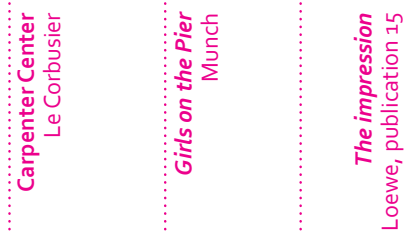

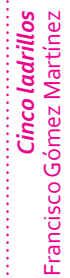

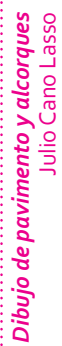

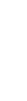

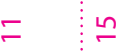

$\bar{m}$

ร

ธ

옹 


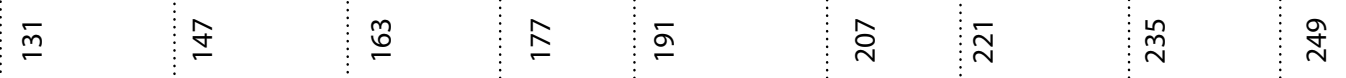

ह단

竞:

을 응

$\frac{\pi}{2} \cup$

을

约

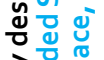

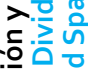

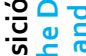

负

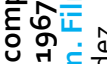

중

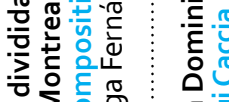

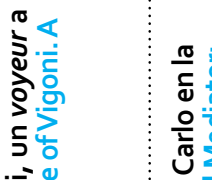

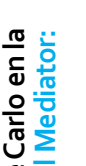

हें

ดั ชั

은 흥영

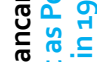

ชั่

ए

ธิ่

过 벙

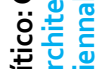

능는

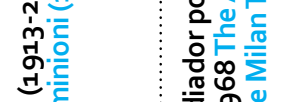

ชั0

हूष

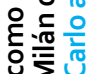

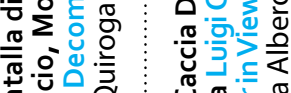

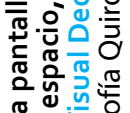

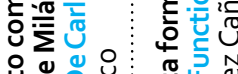

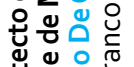

껀

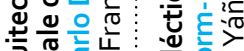

:

혼든 은

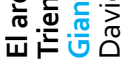

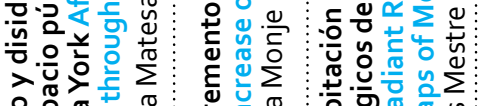

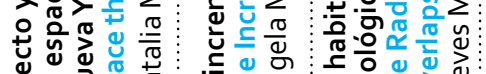

选守之光艺

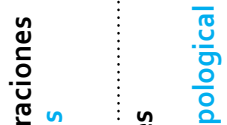

는 흔

กำ $\frac{1}{0} \div$

ถั

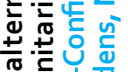

入ว 일

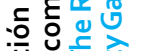

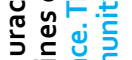

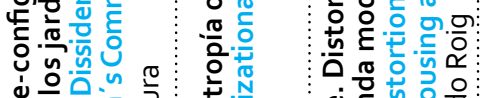

๙

.ํำ $\stackrel{0}{0}$

난.

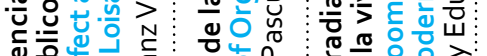

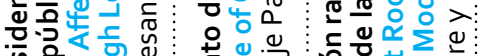

능

త $>\boldsymbol{>}$

ง๋

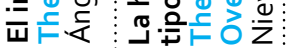
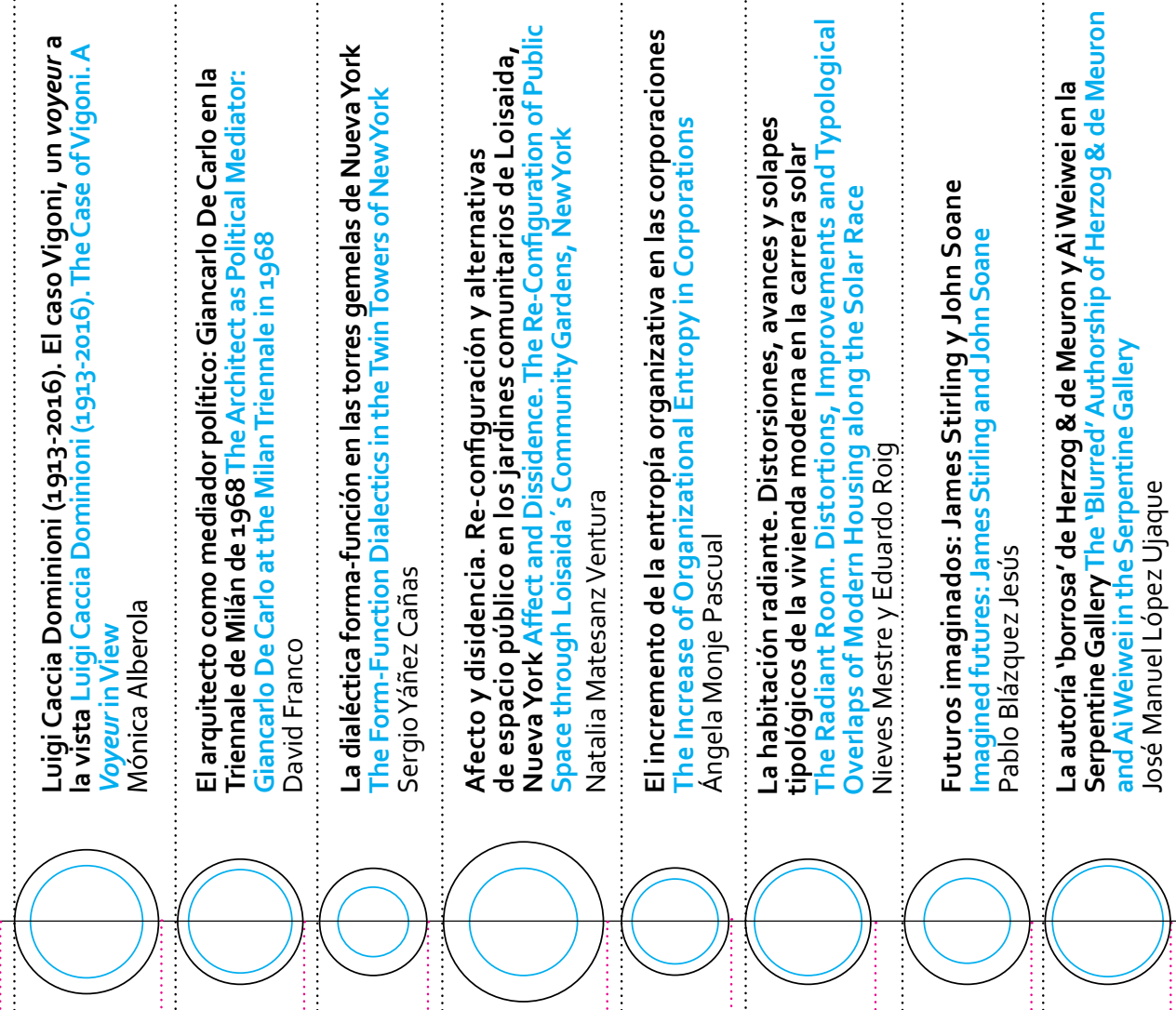

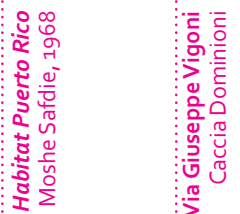

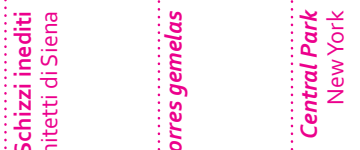

$\sum_{2}^{2}$

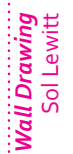

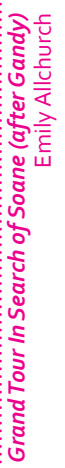

ำ

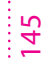

$\stackrel{\circ}{\stackrel{n}{2}}$

$\infty$

ํํำ

$\stackrel{N}{\sim}$

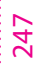

융 గ 


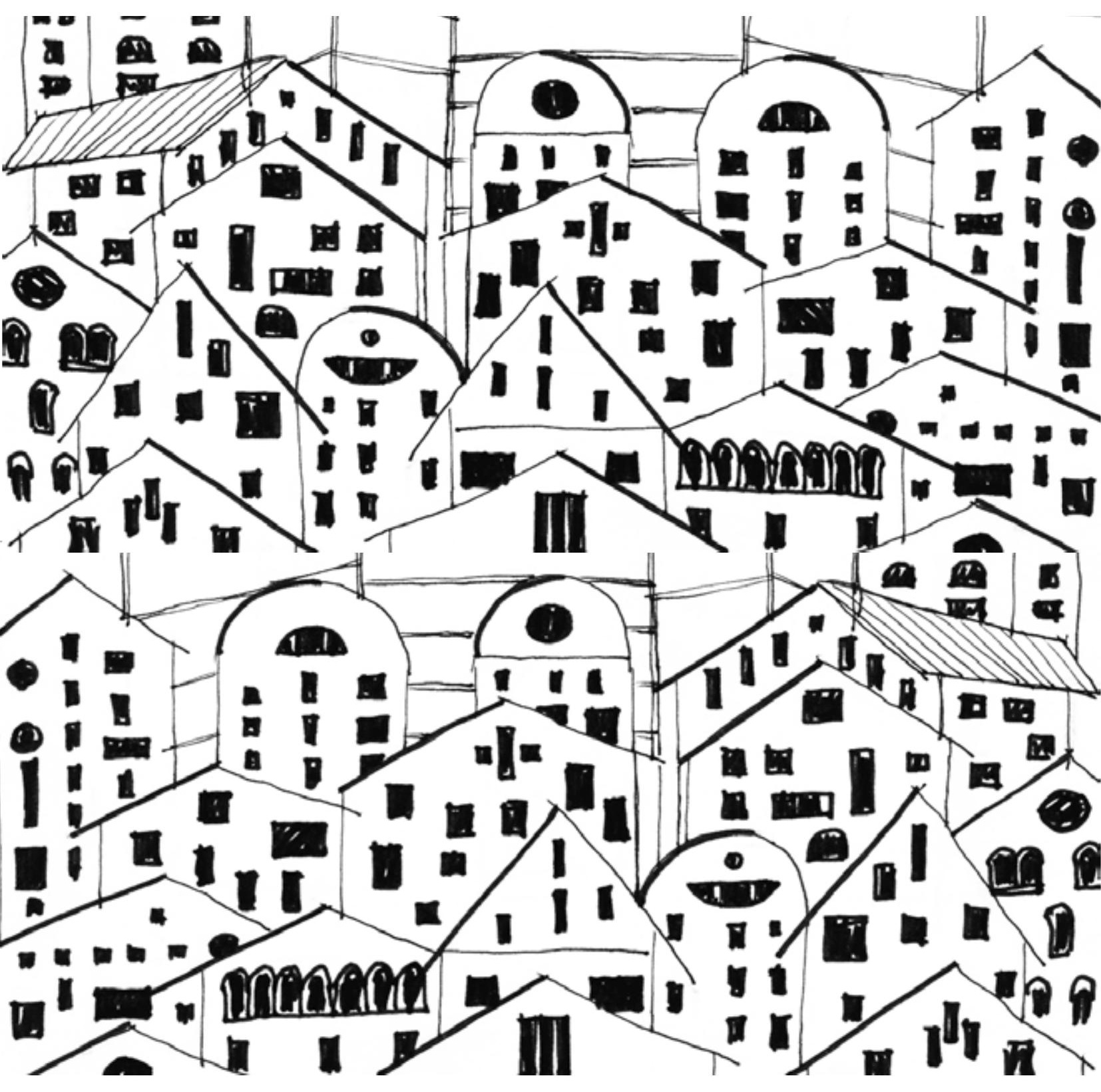




\title{
El arquitecto como mediador político: Giancarlo De Carlo en la Triennale de Milán de 1968
} The architect as political mediator: Giancarlo De Carlo at the Milan Triennale in 1968

\author{
David Franco \\ Clemson University, South Carolina, USA \\ Traducción Translation David Franco
}

Palabras clave Keywords

Giancarlo De Carlo, Guy Debord, Henri Lefebvre, política, 'lo real', Triennale Milán, 1968

Giancarlo De Carlo, Guy Debord, Henri Lefebvre, political, 'the real', Milan Triennale, 1968

\section{Resumen}

El objetivo principal de este texto es el proponer una reflexión crítica sobre el papel del arquitecto moderno como agente de mediación política. El hilo conductor de dicha reflexión es, en primer lugar, la figura y las ideas del arquitecto italiano Giancarlo De Carlo. Usando distintas referencias teóricas que van desde Jaques Lacan a Henri Lefebvre se explora la idea del arquitecto como mediador político de lo real, a través de la experiencia de De Carlo en la Trienal de Milán de 1968. En segundo lugar, se utilizan las herramientas críticas de De Carlo y el concepto de vida cotidiana propuesto por Guy Debord para estudiar la despolitización de la tradición arquitectónica moderna. Finalmente, como conclusión y enlazando las ideas de De Carlo con la lectura crítica de la ciudad de David Harvey, se plantea la posibilidad de la arquitectura como acción colectiva.

\section{Abstract}

The main objective of this text is to propose a critical consideration on the role of the modern architect as agent of political mediation. Firstly, this reflection follows the figure and the ideas of the Italian architect Giancarlo De Carlo. Using different theoretical references, ranging from Jaques Lacan to Henri Lefebvre, the idea of the architect as a political mediator of the real is explored through the experience of De Carlo in the Milan Triennial of 1968. Secondly, De Carlo's critical tools and the notion of everyday life proposed by Guy Debord are used to study the depoliticization of the modern architectural tradition. FinaIly, as a conclusion, and linking the ideas of De Carlo with the critical reading of the city by David Harvey, the possibility of architecture as collective action is proposed. 
La onda expansiva de las protestas de mayo del 68 en París, no solo atravesó barreras geográficas asumiendo reivindicaciones diferentes en cada lugar: los derechos civiles en Estados Unidos, la lucha por la democracia en España o la rebelión por las libertades políticas y en contra del régimen soviético en la antigua Checoslovaquia. Además, el cuestionamiento al poder establecido y a la autoridad, que alimentaban la base de las protestas globalmente, también traspasaron los límites disciplinares afectando a prácticas culturales y políticas de todo tipo. En este contexto, la arquitectura como disciplina quedaba expuesta desde ángulos diferentes: por un lado, por el rol del arquitecto como agente que opera típicamente al servicio del poder dominante; por otro, por la concentración de responsabilidad y capacidad de decisión que la profesión ostentaba en la configuración de la ciudad y finalmente, por su fuerte vinculación al mundo académico, que era percibido como una institución caduca e impermeable al impulso renovador que la sociedad demandaba.

Tal y como el arquitecto italiano Giancarlo De Carlo supo relatar apenas unos meses después del fracaso de los levantamientos de París en una conferencia impartida en Lieja, (1) estas tres críticas eran parte del mismo fenómeno. Según De Carlo, las exigencias de los estudiantes de arquitectura en las protestas de París trascendían lo que ocurría en otros ámbitos, demostrando que se habían dado cuenta de que, más allá de las autoritarias estructuras organizativas de la universidad o de la escasa conciencia política de los profesionales, la pregunta fundamental a la que tanto la profesión como la academia debían someterse se refería, inevitablemente, a la función última de la arquitectura en la sociedad. (2) Según De Carlo, el efecto de dicha toma de conciencia sobre el contexto en el que se produce la práctica de la arquitectura, no podía ser otro que el acercamiento de la misma a sus usuarios. Tal y como relata el arquitecto francés Jean-Louis Cohen, que vivió en primera persona las protestas en la École de Beux-Arts de París y sus efectos posteriores, dicho acercamiento entre arquitectura y realidad social fue la base de un giro radical, tanto en el tipo de proyectos desarrollados por los estudiantes - más comprometidos con programas de vivienda socialcomo en las metodologías docentes y la organización académica de dicha

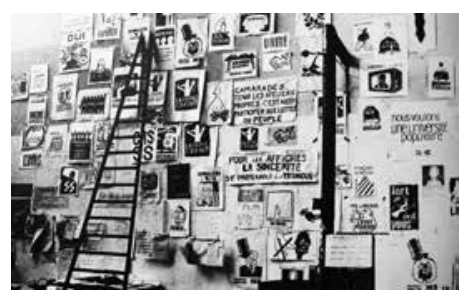

Fig. 1. Posters y carteles en el Atelier Populaire de la Ecole de Beux Arts.

The shock wave of May 1968 protests in Paris not only crossed geographical barriers, assuming different claims in each place: civil rights in the United States, the struggle for democracy in Spain, or the rebellion for political freedom and against the Soviet regime in the former Czechoslovakia. In addition, the questioning of the establishment's authority, which fed the basis of the protests globally, also went beyond any disciplinary limits, affecting cultural and political practices of all kinds. In this context, architecture as an autonomous discipline was questioned from different angles: on the one hand for the role of the architect as an agent that operates typically at the service of the dominant power; on the other, because of the concentration of responsibility and decision-making power that the profession held in the configuration of the city; and, finally, because of its strong link to the academic world, which was perceived as an outdated institution impervious to the transformative impulse demanded by society.

Just as the Italian architect Giancarlo De Carlo argued at a conference held in Liège, (1) only a few months after the failure of the Paris uprisings, these three critiques were part of the same phenomenon. According to De Carlo, the demands of architecture students in the Paris protests transcended what was happening in other areas, demonstrating that they had realized that, beyond the university's authoritarian organization or the lack of political awareness of the professionals, the fundamental question that needed to be answered inevitably referred to the function of architecture in society. (2) If we agree with De Carlo, the effect of such awareness could not be other than the approach of the practice of architecture to its users. As reported by French architect Jean-Louis Cohen, who experienced himself the protests at the École de Beaux-Arts in Paris and its subsequent effects, such reconnection between architecture and its social reality was the basis 
escuela, que evolucionaron a una descentralización en unidades académicas independientes y abiertas a un profesorado joven. (3)

Sin embargo, Cohen puntualiza que la mayoría de los jóvenes arquitectos y estudiantes que participaron en la protestas y la ulterior transformación de la École de Beaux-Arts, (Fig. 1) ignoraban el hecho de que varios miembros del entonces asentado e influyente Team x - como Aldo Van Eyck, Ralph Erskine o el mismo Giancarlo De Carlo- llevaban años experimentando con distintas estrategias de acercamiento a los usuarios. No obstante, las diferencias eran sustanciales. Los miembros del Team $\mathrm{x}$, aunque se distinguían por su crítica a ciertos aspectos de la modernidad canónica, también se consideraban a sí mismos como continuadores del proyecto progresista moderno. Mientras, para los representantes intelectuales de la contracultura del 68, como Henri Lefebvre o Michel Foucault, dicho proyecto se había convertido en el enemigo a batir.

En el centro de este debate encontramos la figura de Giancarlo De Carlo. Por un lado, quizá el miembro del Team x más directamente implicado en la reivindicación del diseño participativo y por otro, uno de los pocos arquitectos de su generación que, además de ejercer la profesión y construir durante años, consiguió desarrollar un sólido discurso teórico a favor de la repolitización de la arquitectura. Este esfuerzo teórico se radicalizó significativamente a partir de las protestas de mayo del 68, por las que De Carlo siempre mostraría respeto y admiración a pesar de la distancia generacional. De ahí su trabajo en exposiciones como las de la Triennale de Milán, o en su labor editorial como director de la revista Spazio y Sozieta desde 1978 hasta 2001. Aldo Van Eyck aprovecharía un texto sobre los edificios universitarios de De Carlo en Urbino para reconocer lo "endiabladamente difícil" de combinar la actividad como arquitecto y la participación en la esfera política sin que una distorsione a la otra: "Una aguda conciencia social de este tipo — con implicación directa- muy fácilmente tiende a dislocar subrepticiamente una estructura de pensamiento significativa. He conocido a un buen número de arquitectos así, doblemente dedicados, pero sólo De Carlo ha conseguido jugar el juego con su propia confusión inicial, de manera inteligente y con desenvoltura”. (4)

of a radical change. A change that affected both the topics developed in the students' projects, more committed to social housing programs, and the teaching methodologies and the academic organization at the École, which evolved towards a decentralization in more independent academic units and opened to a younger faculty. (3)

However, Cohen points out that most of the young architects and students who participated in the protests and the following transformation of the École de Beaux-Arts (Fig. 1) ignored the fact that several members of the then established and influential Team X, as Aldo Van Eyck, Ralph Erskine or even Giancarlo De Carlo, had been collaborating with users for years. Nevertheless, the differences were substantial. Team x members, although critical with certain aspects of canonical modernity, still believed on the modern project. Meanwhile, for the intellectual representatives of the 1968 counterculture, such as Henri Lefebvre or Michel Foucault, modern culture had become the enemy to beat.

At the center of this debate we find the figure of Giancarlo De Carlo. He was not only directly involved in participatory design. More importantly, he was one of the few architects of his generation who, in addition to practicing the profession, successfully developed a solid theoretical discourse in favor of the repoliticization of architecture. Such theoretical effort towards the political significantly radicalized after the 1968 protests, for which De Carlo always showed respect and admiration, despite the obvious generational gap he had with the protesters. His work at the Triennale in Milan, or as editor of Spazio y Sozieta from 1978 to 2001, demonstrate this renewed political urge. In a text about De Carlo's university buildings in Urbino, Team x colleague Aldo Van Eyck praised how De Carlo overcame the "devilishly hard" combination 
Sin embargo, en la intensa atmosfera de protestas del 68, esta capacidad integradora no eximiría a De Carlo de durísimos momentos de conflicto. Como uno de los principales organizadores de la decimocuarta Triennale de Milán, programada para su apertura el 30 de mayo de 1968, tuvo que ser testigo de la ocupación por parte de estudiantes y artistas del Pallazzo dell'Arte, el espacio expositivo de la Triennale, que al igual que la Biennale de Venecia era percibida por muchos jóvenes como una institución cultural al servicio del sistema dominante. (5) Los manifestantes ocuparon el Pallazzo y rápidamente destruyeron gran parte de los materiales expositivos. Después de las reparaciones necesarias, durante la reapertura el 23 de junio, la exposición tuvo que ser protegida por la policía, símbolo máximo de la represión durante el 68. Esto llevó al comité ejecutivo, entre ellos a De Carlo - que no se sentía del todo ajeno a las demandas de los manifestantes - a dimitir en bloque. (6) Paradójicamente, fue un conflicto de carácter político lo que hizo fracasar a esta Triennale - que casi nadie pudo visitar en persona y que no se conoce sino es por fotografías o por la documentación del catálogo-, cuando la temática general impulsada por De Carlo - 'Il grande Numero'- trataba de reflexionar de manera crítica sobre los aspectos sociales que condicionan lo arquitectónico. No olvidemos que la siguiente Triennale, la decimoquinta, encabezada por Aldo Rossi en 1974 y titulada 'Architettura razionale', supuso la consagración del Neoracionalismo de la Tendenza y el comienzo de la reflexión sobre la autonomía crítica de la arquitectura. Desde una perspectiva histórica, no podemos sino interpretar la Triennale de 1968 como una oportunidad perdida para un tipo de crítica menos alejada de la vida cotidiana.

El arquitecto como mediador de lo real. La destrucción de la Triennale de 1968 constituye la escenificación del conflicto interno del proyecto emancipador de la modernidad. Una secuencia de tres imágenes de los eventos de la Triennale, que de un modo u otro tienen a De Carlo como personaje principal, nos ayudará a desentrañar dicho conflicto.

En la primera imagen (Fig. 2) vemos, antes de que la destruyeran junto a las demás, una de las salas de la Triennale en la que se exponía la muestra titula-

of his activity as an architect with the participation in the political sphere without one distorting the other: Acute social awareness of this kind — direct engagement - very easily tends to dislocate surreptitiously — in fact — a meaningful thought structure. I have known quite a few architects thus doubly dedicated, but only De Carlo has managed to play the game with his own initial confusion so intelligently and gracefully". (4)

Nevertheless, in the intense atmosphere of protests in 1968, his integrative skills would not relieve De Carlo from facing harsh moments of conflict. As one of the main organizers of the 14th Milan Triennale, scheduled for opening on May 30 1968, he had to witness the occupation of the exhibition venue - the Pallazzo dell'Arte - by students for whom it was perceived as a cultural institution at the service of the establishment. (5) The protesters occupied the Pallazzo and, quickly, destroyed much of the exhibition materials. After the necessary repairs, during the reopening in June 23rd, the exhibition at the Pallazzo dell'Arte had to be protected by the police-the maximum symbol of repression during 68-, leading the organizing committee, including De Carlo, to resign en bloc. (6) While it was a socio-political conflict which made the most socially charged Triennale fail-limiting out knowledge of it to photographs or catalog documentation — the general approach that De Carlo put forward for the exhibition was, paradoxically, a critical consideration on the social aspects of architecture and the city. Let us not forget that the following Triennale, the 15th, headed by Aldo Rossi in 1974 and entitled 'Architettura razionale' supposed the consecration of neorationalism of the Tendenza, and the beginning of the obsession with the autonomy of architecture. From a historical perspective we cannot but understand the 14th Triennale of 1968 as a missed opportunity for architectural attitudes less removed from everyday life. 
da 'La protestà della gioventù. Era una de las pocas secciones que el mismo De Carlo había diseñado y dirigido en persona, (7) junto al cineasta Marco Bellocchio y al pintor Bruno Caruso. El espacio "reconstruía, pocos días después de los hechos reales, una calle parisina con adoquines, barricadas y jóvenes manifestantes". (8) Las paredes forradas de grandes imágenes de las protestas de París junto a la presencia de restos de barricadas, trataban de construir una propuesta híbrida entre lo cinematográfico y lo arquitectónico: un simulacro realista desprovisto de ironía (9) y que caía inevitable en la misma estetización de una acción auténtica que Peter Burger (10) había criticado a las Neovanguardias. De Carlo intenta aproximar lo que, siguiendo la distinción introducida por Hal Foster, (11) podríamos denominar 'lo real social', es decir el material estético y político que había alimentado el realismo cinematográfico moderno al espacio de la sala de exposiciones, confiando en que la fotografía y la arquitectura serían capaces de confluir, captando la energía social que las protestas liberaron en París.

En la segunda imagen (Fig. 3) vemos el interior del Palazzo dell'Arte tras la ocupación del espacio expositivo de la Triennale. La destrucción va más allá de lo imaginable: además del evidente destrozo de los elementos propiamente expositivos podemos ver trozos de yeso y otros fragmentos que debían ser parte del edificio. A diferencia de otras fotos que documentaron la ocupación, no se ven pintadas u otras señales que expliquen lo que ha ocurrido, solo el puro efecto destructivo de la acción colectiva. Esta segunda imagen contiene, sin rastro de idealización o romanticismo, el aspecto traumático de lo real tal y como lo concebía el pensador y psicoanalista francés Jacques Lacan. Para Lacan la noción de 'lo real' alude a la 'fisicalidad' biológica del cuerpo, a las características más humanamente primitivas de lo material, por lo que constituye una esfera opuesta a la imagen y al símbolo. (12) Lo real es un espacio difícilmente cognoscible por la dificultad intrínseca para explicarlo racionalmente y por eso mismo, es el típico objeto de la ansiedad y del trauma. Frente a la estrategia visual y escenográfica para la representación de la realidad social que De Carlo utiliza en la exposición, lo real traumático de la destrucción de los ocupantes desvela los rasgos inevitables de la acción colectiva: su potencia y su impredecibilidad.
Fig. 2. 'La protestà della gioventù' en la Triennale de Milán de 1968. Giancarlo De Carlo, Marco Bellocchio y Bruno Caruso.

Fig. 3. Escalera del Palazzo dell'Arte en Milán tras el asalto a la Triennale de 1968.
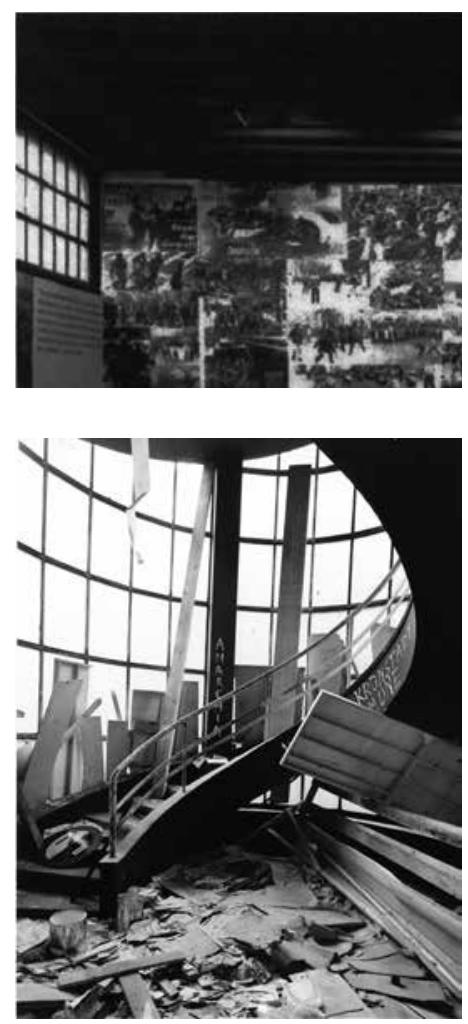

The Architect as Mediator of the Real. The destruction of the 1968 Triennale constitutes the staging of the internal conflict and ultimate failure of the emancipatory project of modern architecture. A sequence of three images of the events of the Triennale, all of them related to De Carlo in one way or another, will help us unravel this conflict.

In the first image (Fig. 2) we see, before it was destroyed with the others, one of the rooms of the Triennale in which the exhibition entitled 'La protestà della gioventù' was being shown. It was one of the few sections that De Carlo himself had designed, together with filmmaker Marco Bellocchio, and painter Bruno Caruso. (7) The space "rebuilt, a few days after the real events, a Parisian street with cobblestones, barricades and young protesters." (8) The walls, lined with large images of the Paris protests, together with the actual physical presence of barricade remains, attempted to create a hybrid between the cinematographic and the architectural: a realistic simulation devoid of irony, (9) and which inevitably fell into the same aestheticization of an authentic action that Peter Burger (10) had criticized the neo-avant-garde. De Carlo attempts to approximate what, following the distinction introduced by Hal Foster, (11) we could call the social real-that is, the aesthetic and political material that had fed the modern cinematographic realism - into the space of the exhibition hall, assuming that photography and architectural space would be able to come together in capturing the social energy that the protests released in Paris.

In the second image (Fig. 3) we see the interior of the Palazzo dell'Arte after the occupation of the exhibition space of the Triennale. The destruction goes beyond the imaginable: in addition to the apparent destruction of the exhibition itself we can see remains of pieces of drywall and other fragments that were part of the building. Unlike other photos that docu- 
La tercera imagen (Fig. 4) sugiere una conclusión negociada a las dos anteriores y es quizá, la fotografía más conocidas de Giancarlo De Carlo. Éste aparece de pie, bien vestido, rodeado por los estudiantes y artistas que protestaban frente al edificio de la Triennale antes de la ocupación. Tenso y con gesto serio discute con ellos, no para aplacarles o convencerles de que se retiren, sino para que entren en el edifico con el objeto de establecer un debate en el marco de la exposición. De Carlo intenta canalizar la energía colectiva de las protestas para convertirla en una vía más del evento oficial - que los que protestaban encontraban burocrático y autoritario-, respetando, sin embargo, el principio de rebeldía colectiva que había originado las manifestaciones. En esta ambición por conciliar 'lo real social' - representable a través de la arquitectura- y 'lo real traumático' - latente en todos los procesos participativos y en ésta última imagen en estado potencial- es donde se encuentra la clave de la repolitización del rol del arquitecto que De Carlo propone.

El entendimiento de la participación en De Carlo no supone, ni la retirada del arquitecto como agente esencial para la producción del espacio, ni la limitación de lo participativo a la redistribución del poder de decisión. La figura del arquitecto aparece, en cambio, como un personaje que incluye como su materia de trabajo los conflictos inherentes entre la vida cotidiana politizada - tal y como la definía Lefebvre- y la estructura organizada de la sociedad moderna. En este sentido, el arquitecto se convierte en un 'mediador de lo real' que debe sacar provecho de su capacidad para trabajar en planos distintos con sensibilidades contradictorias, con el objeto de asegurar la coexistencia entre 'lo real social' y 'lo real traumático', como dos formas de realidad que raramente aparecen unidas en la arquitectura.

La diferencia entre el 'cómo' y el 'por qué. En último término, el efecto más importante del acercamiento de la arquitectura a la sociedad a partir de mayo del 68 es la redefinición del rol del arquitecto frente al modelo moderno, convirtiéndose no solo en un profesional más intelectualizado, como explica JeanLouis Cohen, (13) sino sobre todo, más concernido con áreas de conocimiento paralelas a lo arquitectónico. Esta transformación entronca con la crítica situa-

mented the occupation, we don't see signs or graffiti, only the pure destructive effect of the collective action. This image contains, without a trace of idealization or romanticism, the traumatic aspect of the real as conceived by French thinker and psychoanalyst Jacques Lacan. For Lacan, the notion of the real alludes to the biological physicality of the body, to the more humanly primitive characteristics of the material sphere, constituting a sphere opposed to image and the symbol. (12) The real is a space hardly comprehensible because of the intrinsic difficulty to explain it rationally and, therefore, it is the typical object of anxiety and trauma. Opposed to the visual and scenographic strategy for representing social reality that De Carlo uses in the exhibition, the real traumatic of the destruction of the occupants reveals the inevitable features of collective action: its power and its unpredictability.

The third image (Fig. 4) suggests a negotiated conclusion to the previous two and is, perhaps, Giancarlo De Carlo bestknown photograph. He appears standing, well dressed, surrounded by protesting students and artists right before the occupation of the Triennale. Tense and holding a serious gesture, he argues not to placate or to convince them to leave, but to persuade them to enter the building and establishing a debate within the framework of the exhibition.

De Carlo attempts to channel the collective energy of the protests to bring it into the official event, respecting nevertheless the collective sense of rebellion initiated from the demonstrations. It is in this ambition to reconcile a form of social reality representable through architecture with the traumatic real, which is latent in participatory processes, where the key of the repoliticization of the role of the architect that De Carlo proposes lies. The understanding of participation in De Carlo 
cionista a la especialización: una arquitectura politizada exige un arquitecto más consciente de su contexto global y por tanto, capaz de manejar un cuerpo de conocimiento teórico menos fragmentado y una praxis menos profesionalizada.

En su teorización de la vida cotidiana como espacio desde el que construir la crítica al capitalismo, Guy Debord -el líder intelectual de la Internacional Situacionista- vincula la "parcelación artificial del pensamiento" (14) en campos como la sociología, la antropología e incluso el urbanismo, con la minusvaloración de "el concepto inútil, vulgar y molesto de vida cotidiana". (15) Por tanto, si seguimos a Lefebvre y Debord debemos concluir que, al mantener la vida cotidiana fuera de nuestro alcance, los arquitectos salvaguardamos nuestra disciplina de situaciones de confrontación cultural y política. En palabras de Debord, desde la perspectiva de la especialización, la noción de vida cotidiana encubre "un residuo de realidad catalogada y clasificada con el que a algunos les repugna enfrentarse, pues constituye al mismo tiempo el punto de vista de la totalidad e implicaría la necesidad de

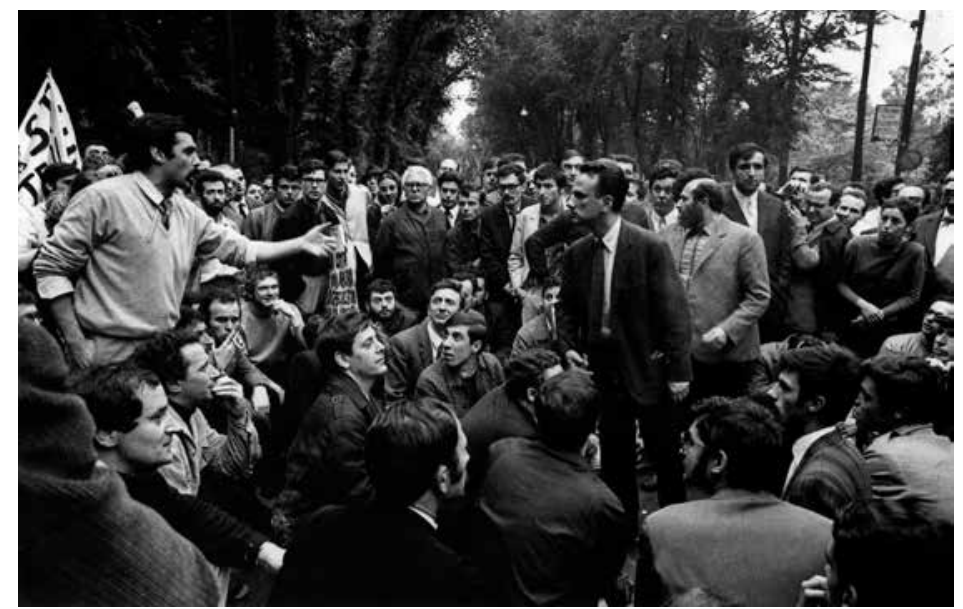

Fig. 4. Giancarlo De Carlo debatiendo frente a los manifestantes en el exterior de la Triennale de Milán de 1968, momentos antes de que les permitiera la entrada a la exposición, que como consecuencia fue completamente destruida.

does not imply either the withdrawal of the architect as an essential agent for the production of space, nor the constraint of the redistribution of decision-making power. The architect appears, instead, as an agent that includes within his work the inherent conflicts between everyday politicized life—as defined by Lefebvre-, and the organized structure of modern society. In this sense, in order to ensure the coexistence between the real social and the real traumatic, the architect becomes a mediator of the real who should take advantage of his ability to work in multiple planes with contradictory sensibilities.

The Difference between the 'Why' and the 'How'. Ultimately, the most important effect of the reconnection of architecture with society after May 68 is the redefinition of the role of the architect against the modern model. Not only he becomes a much more intellectualized professional, as Jean-Louis Cohen explains (13) but, above all, he gets much more concerned with forms of knowledge outside of the strictly architectural. This transformation relates to the Situationist critique of specialization. I that sense, a really politicized architecture requires an architect more aware of its global context and, therefore, capable of managing a less fragmented body of theoretical knowledge as well as a less professionalized praxis.

In his theorizing of daily life as a space from which to build a critique of capitalism, Guy Debord, as the intellectual leader of the Situationists, links the "artificial fragmentation of thought" (14) in fields such as sociology, anthropology and even urbanism, with the underrating of "the useless, vulgar and annoying concept of everyday life". (15) Therefore, if we follow Lefebvre and Debord, we must conclude that by keeping everyday life out of reach, architects safeguard their discipline from situations of cultural and political confrontation. In the words of Debord, from the perspective of specialization, the notion of everyday life 
un juicio global, de una 'política"' (16) No es posible, por tanto, entender la arquitectura como una actividad políticamente activada, a menos que seamos capaces de superar los límites de la especialización.

Los mejores ejemplos de esta rebeldía disciplinar son los propios miembros de la Internacional Situacionista, que en la producción de su trabajo y a veces de manera diletante, no cesaban de saltarse las barreras entre conocimientos especializados. Aunque la literatura situacionista aparece teñida de un lenguaje analítico y revolucionario, que sitúa a sus autores más allá de los valores individualistas de lo artístico, en realidad, como recuerda Javier Maderuelo, "la mayoría de quienes escriben esos textos no son sociólogos, geógrafos, filósofos o urbanistas, sino pintores y escritores que están llevando las herramientas plásticas y poéticas a los límites de sus posibilidades, enfrentándolas a la realidad de sus propias vidas". (17)

Giancarlo De Carlo ha reflexionado también sobre el conflicto entre sensibilización social y disciplina, pero desde una perspectiva historiográfica, explicando el origen del rol del arquitecto moderno. (18) En las sociedades occidentales, el arquitecto como profesional surge durante el establecimiento de la hegemonía de la burguesía en el siglo XviII, identificándose, al igual que otras profesiones que surgieron entonces, como un "representante de la clase en el poder". (19) Según John Kultgen, la propia naturaleza de las carreras profesionales en las sociedades burguesas forzaba la adhesión a instituciones estables, mediante la exigencia de una planificación y un compromiso a largo plazo. (20) El arquitecto, por tanto, encontraba su lugar como profesional en el seno de la burguesía, "siempre y cuando no se preocupara por motivaciones o consecuencias: es decir, siempre y cuando su actividad no aludiera a una condición política más general". (21) La arquitectura fue así impulsada hacia el ámbito de la especialización, “donde sólo los problemas del 'cómo' son importantes, porque los problemas del 'por qué se consideran resueltos de una vez por todas". (22)

Esta limitación se vuelve más problemática en el contexto moderno. De Carlo sostiene que, a pesar del cambio de paradigma técnico y cultural, durante la

conceals "a residue of cataloged and classified reality which some are reluctant to face, because it constitutes at the same time the point of view of the totality and would imply the need for a global judgment, for politics". (16) It is not possible, therefore, to understand architecture as a politically activated activity unless we are able to overcome the limits of specialization.

The best examples of this disciplinary rebellion are the members of the Situationist International who, in the production of their work and sometimes in an openly dilettante manner, constantly skipped the borderlines of specialized knowledge. Although Situationist literature is undoubtedly tinged with an analytical and revolutionary language, which places its authors beyond the individualistic values of the artistic, in reality, as Javier Maderuelo recalls, "the majority of those who write these texts are not sociologists, geographers, philosophers or urban planners, but painters and writers who are taking their plastic and poetic tools to the limits of their possibilities, pushing them towards the reality of their own lives". (17)

Giancarlo De Carlo has also considered the conflict between social awareness and the architecture discipline, but from a rather historiographical perspective, discussing the original social role of the modern architect. (18) The architectural profession as we know it appeared in Western societies during the 18th century bourgeoisie's hegemony, defining itself, like other professions emerged then, as a "representative of the class in power". (19) According to John Kultgen, the very nature of professional careers in bourgeois societies forced adherence to established institutions, by demanding longterm planning and social commitment. (20) The architect, therefore, found his place as a professional within the bourgeoisie, "as long as he did not worry about motivations or consequences: that is, as long as he did not refer his activity to 
primera modernidad se perdió una oportunidad única para modificar el papel del arquitecto como agente de transformación social. El modelo organizativo de los colectivos de arquitectos modernos durante las primeras décadas del siglo xx no lo facilitaba: siempre ordenados en pequeñas élites o incluso completamente autónomos. Aunque es imposible entender la arquitectura moderna sin el trabajo de esta élite de 'héroes solitarios', al desinteresarse de la realidad social propiciaron la aparición de una nueva constelación de actores secundarios "destinados a anular las novedades de éstos, reduciéndolos a símbolos inertes totalmente acordes con los requisitos de la clase dominante". (23) Estos actores se apropiaron rápidamente de las técnicas de la arquitectura moderna, encontrando en la racionalización y simplificación herramientas utilísimas para la burocratización del espacio al servicio del poder económico y político. (Fig. 5) Dichos secundarios incluirían a "los expertos explotadores de superficies útiles, los manipuladores de los códigos de construcción, los legitimadores culturales de la destrucción de la ciudad y el territorio al servicio de banqueros, políticos y burócratas y siempre en detrimento de la gente común". (24)

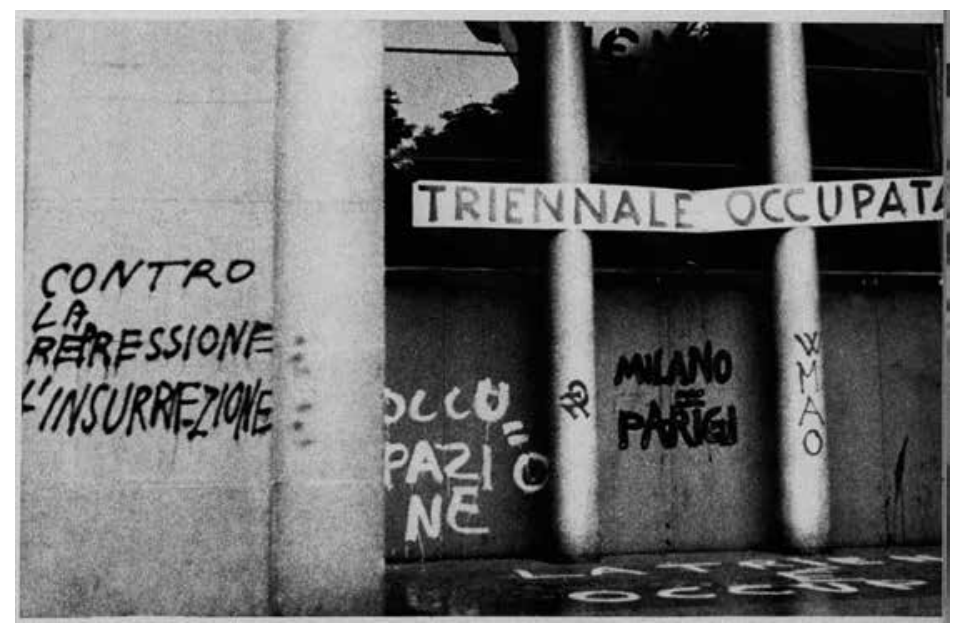

Fig. 5. Imagen de las pintadas en la sede de la Triennale de Milán, durante las protestas de la primavera de 1968 .

a more general political condition". (21) Architecture was therefore driven towards the field of specialization, "where only the problems of 'how' are important, because the problems of 'why' are considered solved once and for all”. (22)

This limitation becomes more problematic in the modern context. De Carlo argues that despite the change of technical and cultural paradigm, during the first modernity a unique opportunity was lost to modify the role of the architect as an agent of social change. The organizational model of the groups of modern architects during the first decades of the Twentieth century did not facilitate it: they were always organized in small elites or, even, completely autonomous. Although it is very hard to explain modern architecture without the work of these elites of 'lonely heroes', by disregarding the social reality they fostered the appearance of a new constellation of a multitude of walk-ons "destined to nullify the novelties of the former, reducing them to inert symbols completely commensurate with the requirements of the ruling class". (23) These actors rapidly appropriated the techniques of modern architecture, finding in rationalization and simplification very useful tools for the bureaucratization of space at the service of economic and political power. (Fig. 5) Walk-ons such as "the expert exploiters of floor-space, the manipulators of building codes, the cultural legitimators of the sack of the city, and the territory organized by financiers, politicians and bureaucrats to the detriment of ordinary people". (24)

The depoliticization of modern architecture implies, therefore, a historical renunciation of a territory of thought and responsibility necessary to fully understand the processes of production of space. Unlike Marxist thinkers such as Henri Lefebvre (25) and David Harvey, (26) who have studied the importance of the production of urban space for modern 
La despolitización de la arquitectura moderna supone, por tanto, una renuncia histórica a un territorio de reflexión y de responsabilidad necesario para entender de una manera completa los procesos de producción del espacio. A diferencia de pensadores de raíz marxista como Henri Lefebvre (25) o David Harvey, (26) que han estudiado la importancia de la producción del espacio urbano para el capitalismo moderno, la explicación que De Carlo da a este hecho no alude a los modos de organización o al contexto productivo de la arquitectura. Es el modo de ejercer por parte de los propios arquitectos y urbanistas lo que explica su propio aislamiento. Para profundizar en esta cuestión, De Carlo propone un par dialéctico muy ilustrativo que distingue entre los problemas del 'cómo' - referidos a estrategias de diseño y a decisiones técnicas especificas de cada proyecto-y los problemas del 'por qué, (27) que explican el contexto político $y$ cultural en el que se enmarcan estas decisiones desde una perspectiva más amplia. La miopía de los arquitectos modernos les llevó a ignorar la complejidad de la totalidad, confiando en cambio, en que a través del diseño, la técnica, las formas y los materiales serían capaces de aludir a cuestiones más amplias. En palabras de De Carlo, "concentrándose en los problemas del 'cómo', le hicieron el juego a las estructuras del poder. Descuidando los problemas de los 'por qué' perdieron la pista de las razones más importantes de su compromiso cultural”. (28)

La despolitización de la tradición arquitectónica Moderna. Utilizando el par crítico 'cómo' y 'por qué' De Carlo analiza dos episodios esenciales en la formación ideológica de la arquitectura moderna: el congreso CIAM de Frankfurt, en 1929, en el cual se delinearon las ideas sobre el mínimo habitacional, y el de Hoddesdon, en 1953, centrado en las problemáticas de 'El corazón de la ciudad'. En ambos casos, la aparente reivindicación de aspectos sociales se resuelve a través de estrategias que no ponen en tela de juicio las problemáticas generales que provocan la escasez de vivienda en Europa, o la destrucción de los centros históricos. Se centran, en cambio, en los 'cómo', es decir, en soluciones que alivian los efectos de estos problemas, pero que no los atacan en su origen. Las recetas que se propu-

capitalism, De Carlo's explanation of this fact does not allude to wider modes of organization or to the productive context of architecture. It is the ways of practicing by architects and urban planners what explains their own isolation. To delve into this problem, De Carlo proposes a very illustrative dialectical pair that distinguishes between the problems of 'how' referring to design strategies and specific technical decisions of each project - and the problems of the 'why' which explain the political and cultural context in which these decisions are framed from a broader perspective. (27) Modern architects' myopia led them to ignore the complexity of the totality, trusting, instead, that through design, technique, forms and materials, they would be able to allude to broader issues. In the words of De Carlo, "concentrating on the problems of' 'how', they played into the hands of the power structure. In neglecting the problems of' 'why', they lost track of the most important reasons for their cultural commitment". (28)

The Depoliticization of the Modern Architectural Tradition. Using the critical pair 'how' and 'why', De Carlo analyzes two essential episodes in the ideological formation of modern architecture: the CIAM Congress in Frankfurt in 1929, in which the notion of minimum housing was delineated; and that of Hoddesdon in 1953, which focused on the problems of 'the heart of the city?. The apparent defense of social aspects is solved in both cases through strategies that do not question the general problems that cause the shortage of housing in Europe, or the destruction of historic centers. Instead, they focus on the 'how', that is, on solutions that alleviate the effects of these problems, but that do not attack them at their origin. The solutions that were proposed-serialization and prefabrication on the one hand, and the recovery of historic centers through commercial and business uses on the other-became part of the ideological arsenal of modernity, losing its relevance as critique. 
sieron -la serialización y prefabricación, por un lado y la recuperación de los centros históricos a través de usos comerciales y de negocios, por otro- pasaron a formar parte del arsenal ideológico de la modernidad, perdiendo su relieve crítico.

En el CIAM de Frankfurt, aunque los arquitectos pensaban que abordando la gran demanda de vivienda en la Europa de posguerra estaban liderando el proceso de modernización de las ciudades, en realidad la cuestión "había sido ya inventada y agravada por el sistema capitalista, que habiendo 'urbanizado' a masas de agricultores para generar mano de obra para la industria sin prever su asentamiento en la ciudad, ahora se encontraba en una situación difícil, atrapado en la red de sus propias contradicciones". (29) El remedio que la pequeña élite reunida en Frankfurt prescribió fue la construcción de viviendas industrializadas lo más baratas, parecidas y pequeñas como fuera posible. La colección de propuestas que emanaron del congreso se convirtió en "la coartada cultural para la especulación económica más feroz y la más obtusa ineficacia política”. (30) Pasarían décadas antes de que la profesión se liberara de la idea de que la diferencia y la amplitud son lujos innecesarios.

En el CIAM de Hoddesdon, en Inglaterra, el ejercicio cultural de reclamar los centros históricos como espacios imprescindibles para el urbanismo moderno - que hasta entonces los había desatendido totalmente- se convirtió en una excusa para transformaciones de carácter político. El efecto final de las propuestas del congreso fueron, como bien sabemos, el desplazamiento a las periferias de las bolsas de población de rentas más bajas, reservando los centros históricos para usos comerciales y de negocios. Pero también para viviendas de las clases más acomodadas, que de este modo y gracias al espectacular aumento de los precios, hacían suyos los espacios comunes en los que se acumula la memoria y la cultura de nuestras ciudades. La irresponsabilidad de la arquitectura como disciplina había contribuido de manera directa a "la expansión de la iniquidad social en su aspecto más feroz y vergonzoso: la segregación de clases en el espacio físico”. (31)

At the CIAM in Frankfurt, although the architects thought that by addressing the great demand for housing in post-war Europe, they were leading the process of modernization of cities, in fact the issue "had already been invented and dramatized by the capitalist system, which having urbanized masses of farmers to generate manpower for industry without providing for their settlement in the city, now found itself in a tight spot, caught in the web of its own contradictions". (29) The remedy prescribed by the small elitist meeting in Frankfurt was the construction of industrialized housing as cheap, similar and small as possible. The collection of proposals originated from the congress became "cultural alibis for the most ferocious economic speculation and the most obtuse political inefficiency". (30) It would take decades before the profession freed itself from the idea that difference and spaciousness are unnecessary luxuries.

In the Hoddesdon CIAM, in England, the cultural exercise of reclaiming historical centers as essential spaces for modern urbanism - which until then had largely ignored them-, became an excuse for transformations of a political nature. The final effect of the congress' proposals was, as we know, the displacement to the peripheries of lower income population groups, reserving historical centers for commercial and business uses. But also for homes of the most affluent classes that, in this way and thanks to the spectacular increase in prices, made theirs the common spaces in which the memory and culture of our cities rest. The irresponsibility of architecture as a discipline had directly contributed to "the expansion of social iniquity in its most ferocious and shameful aspect: the segregation of classes in physical space." (31) 
Como conclusión a esta reflexión, me gustaría llamar la atención sobre la llamativa correspondencia entre los aspectos fallidos de los CIAM de 1929 y 1953 y las principales demandas de mayo del 68. Si, como defiende David Harvey, (32) aceptamos el carácter profundamente urbano de las protestas de París, debemos admitir que la denuncia global de la sociedad de consumo capitalista incluía una crítica muy especifica a la manera en que la ciudad moderna estaba siendo concebida, no sólo por promotores y políticos, sino también y muy especialmente por los arquitectos. En ese sentido, la repolitización de la ciudad, que los situacionistas llevaban demandando durante años, suponía una apertura de arquitectos y urbanistas a lo colectivo. Un cambio que debía afectar antes que nada al propio papel del arquitecto, como personaje que opera de manera aislada evitando, por un lado, entender y asimilar los aspectos políticos de las decisiones que toma y por otro, interactuar con los protagonistas más débiles del proceso que dirige, por no hablar de cederles parte de su poder.

Si, como afirma De Carlo al respecto del modelo moderno, "trabajar en el 'cómo' sin un control riguroso del 'por qué, excluye inevitablemente la realidad del proceso de diseño", (33) la arquitectura que surja como materialización de la crítica a la ciudad moderna apuntada por los protagonistas de mayo del 68, deberá responder a la realidad social antes que a las normas internas de su disciplina. Lo que supone, como adelantaba Debord, restituir la idea de una "vida cotidiana criticada", que si seguimos la definición en negativo de Lefebvre como "lo que queda cuando sustraemos todas las actividades especializadas", (34) se situará forzosamente fuera de la práctica especializada de la arquitectura. Desde esta perspectiva, la práctica arquitectónica realista que surge de la cultura del 68 se politiza mientras disuelve la especialización de la tradición moderna, abriéndose a la participación de los usuarios. Un nuevo tipo de práctica crítica de la arquitectura surge así, conectada siquiera tangencialmente con las propuestas del Situacionismo sobre la ciudad y superando el mundo de lo teórico, para hacerse realidad a través de la pura praxis, es decir, a través de la acción colectiva.

As a conclusion to this text, I would like to draw attention to the striking similarity between the failed aspects of the CIAMs of 1929 and 1953, and the main demands of May 68 protesters. If, as David Harvey defends, (32) we accept the deeply urban character of the protests in Paris, we also should acknowledge their general criticism of capitalist consumer society included a specific critique of the way in which the modern city was being conceived, not only by promoters and politicians, but also by architects. In this sense, the repoliticization of the city, which the Situationists had been demanding for years, meant a breach into collectiveness for architects and urbanists. A change that had to affect the architect's own role as an agent that essentially operates in isolation, avoiding, on the one hand, understanding and assimilating the political aspects of the decisions he makes, and on the other hand, interacting with the weakest protagonists of the process that he directs, let alone giving them part of his power.

If, as De Carlo says about the modern model, "working on 'how' without rigorous control of 'why' inevitably excludes reality from the planning process", (33) the architecture that emerges from the critique to the modern city pointed by the protagonists of May 68, ought to respond to its social reality before to the internal rules of its discipline. Which also entails, as Debord advanced, to restore the idea of a "criticized daily life" that, if we follow the negative definition of Lefebvre as "what remains when we subtract all the specialized activities", (34) will be necessarily outside the specialized practice of architecture. From this perspective, the realist architectures that emerges from the culture of 1968 becomes political while dissolving the specialization of the modern tradition, and opening itself to the participation of its users. Therefore, a new form of critical architectural practice related, even tangentially, with the Situationists' proposals on the city emerges, overcoming the theoretical sphere to become a reality through pure praxis, that is, through sheer collective action. 


\section{NOTAS}

1. DE CARLO, Giancarlo. 'Architecture's Public' en Architecture and Participation. TILL, Jeremy (ed.). Londres: Taylor, 2005, pp. 3-22.

2. Ibíd., p. 4.

3. COHEN, Jean Louis. 'Populists Mirages', $\log$ n. 13/14. Aftershocks: Generation(s) since 1968, otoño 2008, pp. 53-58.

4. VAN EYCK, Aldo. 'University College in Urbino by Giancarlo De Carlo', Zodiac n.16, enero-febrero 1966.

5. NICOLIN, Paola. 'Beyond the Failure: Notes on the 24th Triennale', $\log n$. 13/14, Aftershocks: Generation(s) since 1968, otoño 2008, pp. 87-100. 6. ZARDINI, Mirko. 'The 14th Triennale' en Team X, 1953-1981: In Search of a Utopia of the Present, RISSELADA, Max; van den HEUVEL, Dirk (eds,). Rotterdam: NAi, 2005.

7. Giancarlo De Carlo ejercía de responsable de la organización y temáticas globales de la Triennale.

8. ZARDINI, 'The 14th Triennale'. Op. cit.

9. La reacción de los ocupantes del edificio con lo que encontraron en la sala de 'La protestà della gioventù' fue especialmente dura. Si las pintadas en el exterior del edificio decían Milan=Parigi o Triennale Occupata, en esta sala criticaban específicamente la bienintencionada simulación que De Carlo había compuesto: La Triennale no es París - Merde a los falsificadores. Véase: ZARDINI, 'The 14th Triennale'. Op. cit.

10. BURGER, Peter. Theory of the Avant-Garde. Minneapolis: University of Minnesota Press, 1984.

11. Siguiendo la distinción introducida por Hal Foster entre 'lo real social', de origen socio-político y 'lo real traumático', de origen psicoanalítico, en un término que se toma prestado del trabajo de Jacques Lacan. Véase: FOSTER, Hal. El retorno de lo real. Madrid: Akal, 2002.

12. EVANS, Dylan. An Introductory Dictionary of Lacanian Psychoanalysis. London: Verso, 1996, p. 163.

13. COHEN, Jean Louis. 'Populists Mirages', Log n. 13/14. Aft ershocks: Generation(s) since 1968, otoño 2008, p. 53-58.

14. DEBORD, Guy. 'Perspectivas de modificación consciente de la vida cotidiana', Internacional situacionista vol. I, La realización del arte. Madrid: Literatura Gris, 1999.

15. Ibíd.

16. Ibíd.

17. MADERUELO, Javier. La idea de espacio en la arquitectura y el arte contemporáneos, 1960-1989. Madrid: Akal, 2012, p.180.

18. DE CARLO, Giancarlo. 'Architecture's Public', Architecture and Participation. TILL, Jeremy (ed.). Londres: Taylor, 2005, p. 5.

19. Ibíd.

20. KULTGEN, John. Ethics and Professionalism. Nueva York: University of Pennsylvania Press, 1998, p. 111.

21. DE CARLO, Op. cit., p. 5.

22. Ibíd.

23. Ibíd.p. 7.

24. Ibíd.

25. LEFEBVRE, Henri. El derecho a la ciudad. Barcelona: Peninsula, 1978. 26. HARVEY, David. 'The Right to the City', New Left Review n. 53, septiembre-octubre, 2008.

27. Este planteamiento es una de las reivindicaciones que recientes publicaciones sobre el trabajo de De Carlo han tratado de rescatar por su validez para escenarios más actuales. MEYBOOM, Annalisa. 'Giancarlo De Carlo and the Question of Why', 99th ACSA Annual Meeting Proceedings, Where Do You Stand. CORMIER, Annie (ed.). Annie Pedret \& Alberto Perez-Gomez, 2011. 28. DE CARLO, 'Architecture's Public', Op. cit., p. 8.

29. Ibíd.

30. Ibíd., p. 9.

31. Ibíd., p. 11.

32. HARVEY, David. 'The Right to the City', New Left Review n. 53, septiembre-octubre, 2008.

33. DE CARLO, 'Architecture's Public', Op. cit., p. 9.

34. DEBORD, Guy. 'Perspectivas de modificación consciente de la vida cotidiana' en Internacional situacionista vol. I: La realización del arte. Madrid: Literatura Gris, 1999.
NOTES

1. DE CARLO, Giancarlo. 'Architecture's Public' en Architecture and Participation. TILL, Jeremy (ed.). Londres: Taylor, 2005, pp. 3-22.

2. Ibid., p. 4.

3. COHEN, Jean Louis. 'Populists Mirages', $\log$ n. 13/14. Aftershocks:

Generation(s) since 1968, fall 2008, pp. 53-58.

4. VAN EYCK, Aldo. 'University College in Urbino by Giancarlo De Carlo',

Zodiac n.16, January-February 1966.

5. NICOLIN, Paola. 'Beyond the Failure: Notes on the 24th Triennale', $\log$ n. 13/14, Aftershocks: Generation(s) since 1968, fall 2008, pp. 87-100.

6. ZARDINI, Mirko. 'The 14th Triennale' en Team X, 1953-1981: In Search

of a Utopia of the Present, RISSELADA, Max; van den HEUVEL, Dirk (eds,). Rotterdam: NAi, 2005.

7. Giancarlo De Carlo acted as main responsible for the organization of the global themes of the Triennale.

8. ZARDINI, 'The 14th Triennale'. Op. cit.

9. The reaction of the occupying group with what they found at the exhibition room La protestà della gioventù' was specially harsh. If the signs on the exterior of the building said Milan=Parigi or Triennale Occupata, in this room they specifically criticized the well-meaning simulation composed by De Carlo's team: The Triennale isn't Paris - Shit to the fakers. See: ZARDINI, 'The 14th Triennale'. Op. cit.

10. BURGER, Peter. Theory of the Avant-Garde. Minneapolis: University of Minnesota Press, 1984.

11. Here I follow the distinction introduced by Hal Foster between the 'real social', of socio-political origin, and the 'real traumatic', of psychoanalytical origin, in a terminology borrowed from de Jacques Lacan's works. See:

FOSTER, Hal. El retorno de lo real. Madrid: Akal, 2002.

12. EVANS, Dylan. An Introductory Dictionary of Lacanian Psychoanalysis. London: Verso, 1996, p. 163.

13. COHEN, Jean Louis. 'Populists Mirages', Log n. 13/14. Aft ershocks: Generation(s) since 1968, otoño 2008, pp. 53-58.

14. DEBORD, Guy. 'Perspectivas de modificación consciente de la vida cotidiana', Internacional situacionista vol. I, La realización del arte. Madrid:

Literatura Gris, 1999.

15. Ibíd.

16. Ibíd.

17. MADERUELO, Javier. La idea de espacio en la arquitectura y el arte contemporáneos, 1960-1989. Madrid: Akal, 2012, p.180.

18. DE CARLO, Giancarlo. 'Architecture's Public', Architecture and Participation. TILL, Jeremy (ed.). Londres: Taylor, 2005, p. 5.

19. Ibíd.

20. KULTGEN, John. Ethics and Professionalism. Nueva York: University of Pennsylvania Press, 1998, p. 111.

21. DE CARLO, Op. cit., p. 5.

22. Ibíd.

23. Ibíd. p. 7.

24. Ibíd.

25. LEFEBVRE, Henri. El derecho a la ciudad. Barcelona: Peninsula, 1978.

26. HARVEY, David. 'The Right to the City', New Left Review n. 53,

September-October, 2008.

27. This approach is borrowed from recent publications about De Carlo's work, which have defended its validity for more recent scenarios. MEYBOOM, Annalisa: 'Giancarlo De Carlo and the Question of Why' in 99th ACSA Annual Meeting Proceedings, Where Do You Stand ed. CORMIER, Annie (ed.), Annie Pedret \& Alberto Perez-Gomez, 2011.

28. DE CARLO, 'Architecture's Public', Op. cit., p. 8.

29. Ibíd.

30. Ibíd., p. 9.

31. Ibíd., p. 11.

HARVEY, David. 'The Right to the City', New Left Review n. 53, tember-October, 2008.

3. DE CARLO, 'Architecture's Public', Op. cit., p. 9.

34. DEBORD, Guy. 'Perspectivas de modificación consciente de la vida cotidiana' en Internacional situacionista vol. I: La realización del arte. Madrid: Literatura Gris, 1999. 


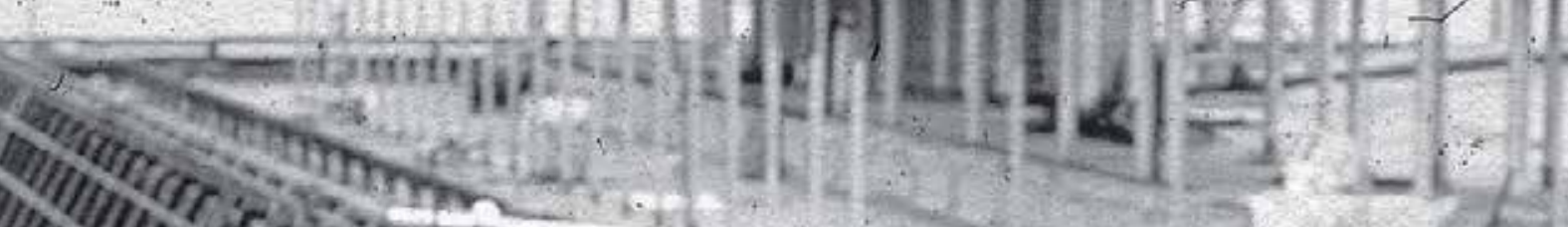

(40,

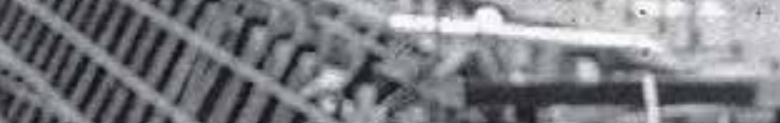

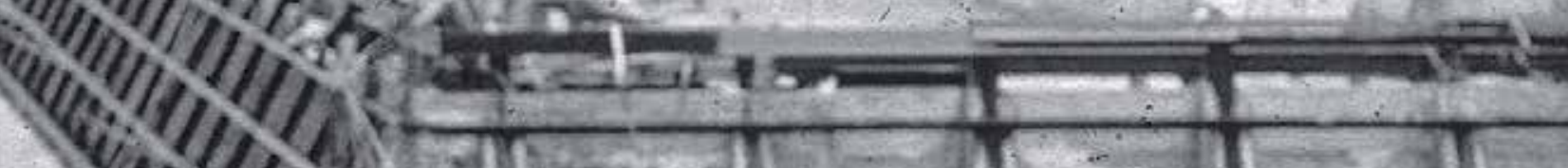

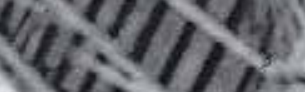

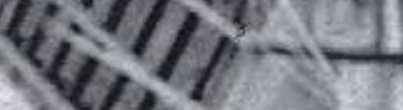
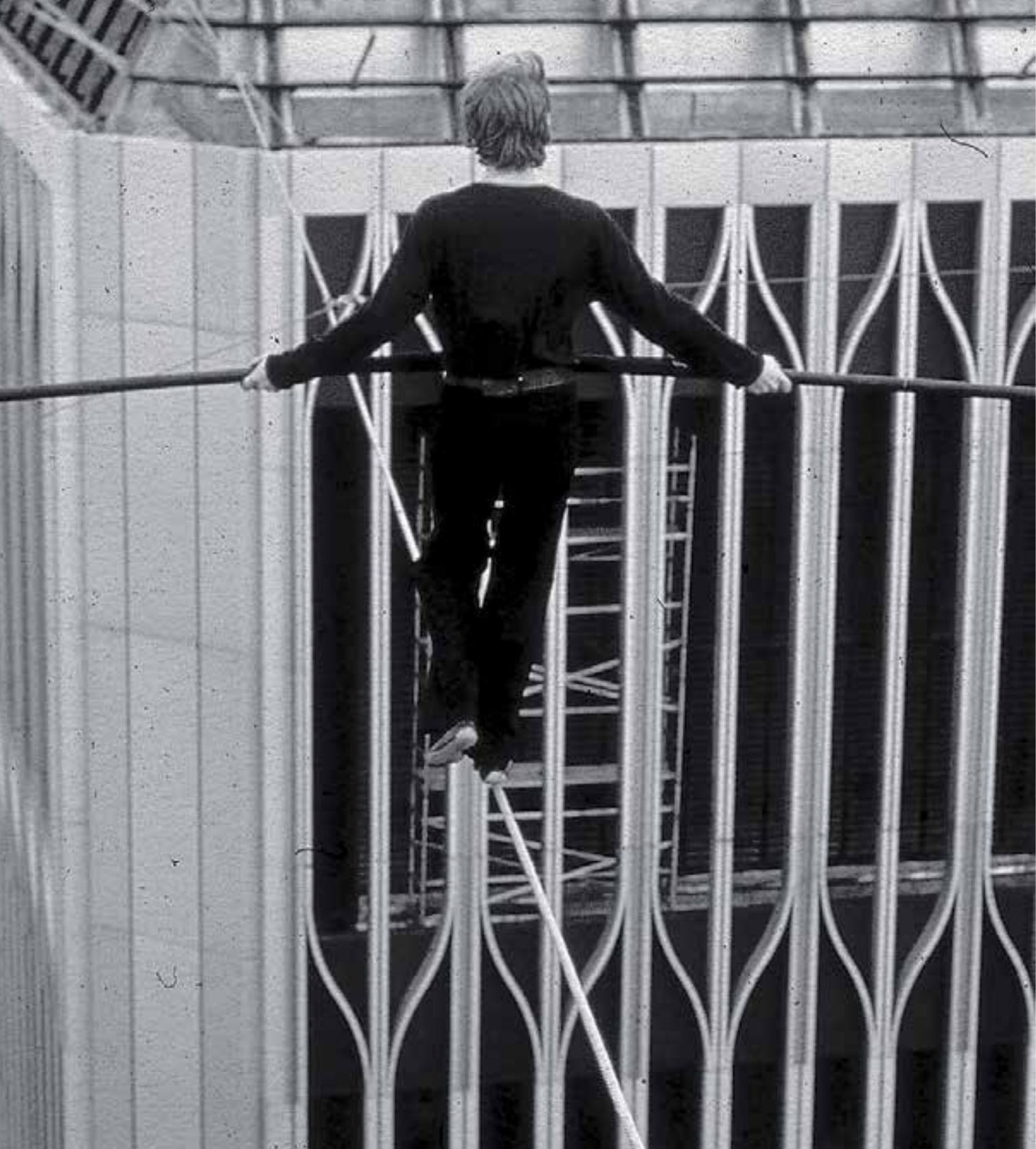